\title{
The Contribution of Internal Locus of Control and Self-Concept to Career Maturity in Engineering Education
}

\author{
Hendra Hidayat, ${ }^{\mathrm{a}, 1}$, Boy Yendra Tamin ${ }^{\mathrm{b}}$, Susi Herawati ${ }^{\mathrm{a}}$, Zadrian Ardic, ${ }^{\mathrm{c},}$, Anggarda Paramita Mujic \\ ${ }^{a}$ Education and Training Faculty, Universitas Bung Hatta, Aie Pacah street, Padang, 25174, Indonesia \\ E-mail: ' hendrahidayat@bunghatta.ac.id \\ ${ }^{b}$ Faculty of Law, Universitas Bung Hatta, Aie Pacah street, Padang, 25174, Indonesia \\ e-mail: boy@boyyendratamin.com \\ ${ }^{c}$ Education Science Faculty, Universitas Negeri Padang, Hamka street, Padang,25132, Indonesia

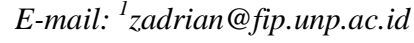

\begin{abstract}
Students are faced with the choice to continue their education to a higher level of work after completing their education, including engineering education students. However, the fact is that the students who have completed their education cannot determine the career planning direction. This phenomenon implies that students do not have career maturity, especially in entrepreneurship. Career maturity is influenced by several factors, including locus of control and self-concept. This study aims to describe the internal locus of control, self-concept, and career maturity, test the contribution of internal locus of control and selfconcept towards the career maturity of engineering education students in entrepreneurship. This study used multiple regression analysis. The research sample was 218 people consisting of students at private universities in West Sumatra, Indonesia. Data collection was done by using inventory Locus of Control and Self Concept. The research findings show that: (1) on average, the description trust of internal locus of control is in the high category, (2) the self-concept is in a positive category, (3) career maturity is in the high category, (4) there is the contribution of locus of control internal to career maturity of $7.5 \%(R=0.275$, the significance of $0.000),(5)$ there is a contribution of self-concept to career maturity of $7.2 \%(R=0.268$, the significance of 0.000$)$, and $(6)$ there is a joint contribution of locus of internal control and self-concept of career maturity by $11 \%(R=0.332$, significance 0.000$)$.
\end{abstract}

Keywords — internal locus of control; self-concept; career maturity; engineering education.

\section{INTRODUCTION}

Education is an important ingredient in providing life change and improving the welfare of a nation. Education helps change mindsets and have an impact on the country's economy. A society with high education makes it possible to compete and compete on a national and international scale; with the challenges of living in this technological era, mastery of science and technology becomes a necessity for the people in the country. This form of competition is a cross-regional economy, for example, in trade in goods, services, and investment. Therefore, education must be able to respond and answer these challenges. In general, education aims to prepare students or human resources to face competition that is so competitive in life and earn a living (work and create jobs). Engineering education graduates have a more dominant mindset in looking for work, quite rarely from engineering education graduates trying to generate new jobs and create jobs. Opportunities and desires to open their own jobs certainly are also influenced by how learning activities that have been carried out in higher education. Higher education implements learning tends to be limited to the transfer of knowledge and information, has not touched on building student experience. Learning that builds and shapes entrepreneurial enthusiasm and competence in tertiary education is urgently needed so that graduates of engineering education in tertiary institutions could survive in society and are able to compete with the existing job market. And it is expected that college graduates (engineering) can produce many young entrepreneurs, which directly increase the country's economic figures.

Career development in engineering education deals with the selection of jobs, which are the basis for the development of engineering education. This is because engineering education aims to prepare students to enter the workforce. At the same time, the work will be done well if the work is in accordance with what is in their interests. Furthermore, career development in engineering education is also equipped with skills competencies in the fields of science 
and entrepreneurship, especially entrepreneurial careers, which are very much a spearhead in dealing with educated unemployment from engineering education graduates. After graduating, students are faced with several choices, namely given the opportunity to continue their education at the next level or choose to have a career and work in a place [1], [2]. Taking attitude and action on this choice is a very decisive part in the lives of students in the future [4]. In fact, there are students who have graduated in education also have difficulty in finding the next career planning direction [8].

One of the consequences of this phenomenon is that college graduates who are expected to be the driving force and contribute to the number of entrepreneurs in Indonesia are just the opposite. Based on data held by the Central Bureau of Statistics, Indonesia [9], [10], about the Open Unemployment Rate starting from February 2016 for 7.02 million people or 5.5 percent, in August 2016 was 7.03 million people or 5.61 percent, and finally, in February 2017 was 6.68 million people or 5.33 percent, this figure includes unemployed education graduates (educated unemployment), this is certainly due to various factors. One of them is the ability to survive in a society with entrepreneurial competencies that are influenced by entrepreneurial maturity career [11].

Planning a career choice is a picture of someone's life to prepare them and understand their environment. Unlike career choice planning, career choice is a process of developing a career plan that he wants to do in the future. In other words, in order to enter a certain position or expertise, a provision of relevant skills and skills can be obtained from a certain type of educational program. Career choice is the desire or aspirations of someone after completing his studies at a certain level of education, which includes involvement in the process of choice, orientation towards work, and determination of career decision making based on knowledge about his own self and the work to be entered. In addition, career choice is an expressive action that reflects the motivation, knowledge, personality, and ability of a person in choosing a career. In some cases, this career choice refers to certain types of information, motivation, knowledge, career problems, his understanding and the insights and abilities he has.

This degree of career choice is determined by the extent to which students choose the type of education that is relevant to the job title they want to enter later. Based on some of the above meanings, it can be concluded that career choice is to determine and make work decisions that want to be pursued throughout a person's life and be used as a source of livelihood later. There are factors that influence career choices originating from individuals [3]-[7], including:

1) Intellectual ability: The intellectual abilities possessed by an individual play an important role, because the intellectual ability of a person can be used as considerations in entering a job, position, or career and as a complement in considering entering a certain level of education

2) Talent: It should be as early as possible the talents possessed by a child in the school are known in order to provide learning guidance that best suits his talents and predicts the fields of work, position, or career of the students after completing his studies.

3) Interest: Interest is very influential in achieving a job position or career. If someone is not interested in a job he occupies, then that person cannot finish his job properly. So that the person becomes uncomfortable or easily bored with the job he occupies.

4) Attitude: Attitude is a relatively stable tendency that is possessed in reacting to others or certain situations. But in adolescence, there are changes in attitude and behavior. This is due to the influence of their peers. Because currently, adolescents could involve themselves in various social activities so that adolescence is increasingly widespread.

5) Self-concept: Self-concept is very influential on career choices; in terms of career choice reflects self-concept. A person who can choose a career in accordance with his concept, then the person is able to judge against his chosen career choice.

6) Value: The value adopted by the individual influences the work is chosen and influences achievement in the work. Every individual has their own values at work, and the values adopted by individuals that are different from the values adopted in work. For example, individuals who have the value that someone who has worked for a company for years deserves to get a salary with that person, ie the employee or employee does not need a salary increase because what he has received according to the company is sufficient and old-age benefits. But the value adopted by the company is different from that person, i.e., employees or employees do not need to recognize salary because what they get according to the company is sufficient.

7) Skills: Skills in certain fields also greatly influence one's choice of position. If someone does not have special skills such as foreign language skills, can operate a computer, etc., then that person will be unable to compete with people who have special skills. By having special skills, the person can be accepted in the company or agency intended by job seekers. In addition, they have skills different from those possessed by others.

8) Use of leisure time: The use of leisure time also greatly determines one's career choice. Free time can be utilized with useful activities, such as user activities such as writing articles, reading books or newspapers, gardening and so on.

9) Hobbies or hobbies: Every individual has a different hobby; such in the field of composing, writing articles, etc. tend to identify their careers according to their hobbies. With his hobbies, someone can choose a job that fits his hobby. This will affect the performance of the job he occupies.

10) Work experience: Work experience is a provision for someone to enter the workforce. With work experience gained, the person will be ready to enter the workforce. Conversely, people who do not have work experience will not be ready to enter the workforce. In this situation, they do not know the tasks that will be carried out later. 
11) Physical appearance: Physical appearance is also very influential on career choice. If someone is not neat, the person is most likely not accepted at work because physical appearance is a picture of the person's personality.

12) Personal problems: Problems or problems from themselves can also influence the choice of career. Individuals who experience problems will solve the problem in a way that is good without emotion, so that you can expect when facing problems at work later, will solve it in a good way too.

Research shows that $82 \%$ of Indonesian students entering higher education do not get proper preparation in choosing majors, including engineering education [12]. In addition, the findings from the data revealed by students also showed that consideration of the potential conditions and opportunities of students in the majors to be selected has not become a basis in the selection of majors. Data shows that in 2010 or $50 \%$ of students in Canada failed to complete their studies in 5 years. It was because the students moved majors on the grounds that their own majors were not as expected and then looked at other majors which were more interesting [13].

The condition of the phenomenon of entrepreneurship career maturity is closely related to sectoral and global economic development [14]. So, the attention to this is a strategic target of national development. This is a study that is assumed to have a career that is very important to do [14] - [16]. Individuals who are not prepared for career selection and inappropriate career selection are caused by low career maturity [11]. This phenomenon shows that students have career maturity in determining career direction appropriately, this is a manifestation of the importance of maturity in future career selection [5]. More clearly, the basic skills in a good career selection process are when individuals have the career maturity [3], [11]. Basically, career maturity will determine in career selection, the condition of student confusion in choosing a career will also be avoided. [3].

Career maturity is a condition of one's readiness to complete various developmental tasks (careers) at each stage of development [5], [17]. It divides the career development stages into five stages. They are growth (4-10 years old), exploration (age 14-24 years), formation (age 24-44 years), maintenance (age 44-64 years), and decline (age 65 to death) [18]. Students are included in the exploration stage, so that career maturity at that time is defined as how capable individuals make career choices and the level of knowledge about education and employment choices [5].

The big challenge in career preparation is how individuals who enter the world of work and higher education can prepare themselves in creating jobs, not "looking for existing jobs". The increase in educated unemployment is an important manifestation of the unpreparedness of universities in developing entrepreneurship-based education systems, including preparing learning environments and variations in the learning process [19]-[21].

Entrepreneurial career maturity is a condition that is influenced by many factors, including psychological factors. One of the dominant influences on entrepreneurial career maturity is the locus of control and self-concept [11]. Locus of control is a person's perception of an event (in the form of success and failure), where the perception is closely related to the power of control in a person, both internal and external [22]. Locus of control has two main dimensions, consisting of internal and external [23]. Internal locus of control is a belief that all forms of behavior and effort alone will affect events and lives that will be lived now and, in the future, [24]. While the external locus of control is the individual's self-belief that everything in him/her (his/her destiny) is determined by factors from outside the self [23].

In daily life, individuals are expected to have control in the form of internal locus of control, the ability to remain in the internal locus of control because it will have positive implications on the development of individual life to make work more successful [25]. The types of the personality of internal locus of control contribute significantly to the condition of one's career maturity [26]. Many different conditions occur in individuals with an external locus of control. These individuals will have confidence that their destiny and condition are determined by the influence of others, the role of luck or coincidence, and the belief that the world is too complicated to predict. This belief will make it difficult for individuals to build a relationship between the results they achieve and their own actions. Another possibility that is also detrimental is the tendency for lazy behavior to try something; they assume that any amount of effort will not guarantee success [27].

Furthermore, the factors that influence career maturity are self-concept. Self-concepts are perceptions, observations, and judgments about it and in relation to others in their lives [28]. Self-concept is an important component to be owned by individuals because, with the belief that all achievements are determined by effort, skill, and ability, students will try to improve their abilities and skills, which are career requirements [24]. Self-concept is related to the typical job choices and positions that will be held by someone. The result of the study shows that self-concept and career maturity has developed alongside physical growth and cognitive development [29]. The entrepreneurial career maturity phenomenon requires an in-depth study through research by looking at the contribution of Locus of Control factors and self-concept. The findings of this research will reveal the condition of the contribution of these two factors to the career maturity of students in higher education so that these findings will be able to analyze an effective roadmap in developing entrepreneurship education in higher education.

\section{MATERIAL AND METHOD}

The sample in this study consisted of 218 students from engineering higher education in West Sumatra, Indonesia, who have completed the study and are looking for a job. The sampling used random sampling technique by considering Power Measurement power to avoid errors $\alpha$ and $\beta$ [30]. Power Measurement Analysis used G* Power Software and actual power of 0.953 with the prediction of 48 samples. The samples of the respondents have been statistically strong. The research sampling process refers to the diversity of demographics and in accordance with the objectives. The locus of control condition data collection was done with Locus of Control Inventory (LCI) [31] which has been validated and adapted into the Indonesian language. Personal 
Self-Concept Inventory (PSCI) [32] with five alternative answers for each item on the scale. First, the research process is carried out by collecting data using a random list of questions distributed to respondents by asking for approval in filling in the data. The data is then analyzed using multiple regressions.

\section{RESULTS AND DISCUSSION}

Engineering education aims to develop the potential of students to prepare to enter the workforce and have the character and spirit of entrepreneurship [33]-[36]. An important part in preparing to enter the world of work is certainly very determined about how students in engineering higher education properly understand the direction and career maturity that will later be decided and chosen. This explanation is in line with the theory of career development.

The theory of career development raises [37], [38], by stating that career development that is a continuous process, generally not recurring, regular occurrences, structured forms, and dynamic. It involves interactions between individual behaviours, resulting in continuity between demand and supply work in society. This theory concerns four basic concepts which are elaborated into 11 parts, and each consists of several characteristics:

First, the nature of the development of engineering education has several characteristics:

- Development of engineering education is a continuous and generally non-repetitive process.

- The development of engineering education is a regular occurrence, the shape is structured, and the results can be predicted.

- Vocational development is a dynamic and synthetic process.

Second, the career type selection process includes:

- Selection of the type of career begins with selfconcept since approaching adulthood, becomes clear when the child becomes an adult and is transferred into stability towards a particular career.

- The reality that exists in him (individual) and those around him (society) is a very decisive factor in choosing the type of career and is a function of the development of the age of the child to become an adult.

- Understanding of parents or children responsible for the type of career, role and relationship of parents and children, will affect the planning and selection of career types.

Third, factors that influence career formation;

- Selection of several types of multi-level careers (from low to high) will be related to children's intelligence, parents' socio-economic level, level of needs, values, desires and ideas, communication skills with others, and balance between provision and economic demand.

- The career fields that individuals enter are related to desires and judgments, parents' attention, the source of information they obtain, the level and type of education, career structure, trends, and attitudes of the community.

Fourth, Predict individual career success:
- Although every career requires the ability, desire, and activity to choose, in career vision, there is tolerance among various types of careers from individuals.

- Peace in the workplace depends on the degree to which an individual can apply his abilities, achieve his goals, and accept the applicable values.

- The level of satisfaction gained in work will be related to the extent to which they can apply the self-concept they have at their place of work.

\section{A. Internal Locus of Control}

The result of the study in Table 1 shows more than $80 \%$ of the achievement and life before. There are $4.6 \%$ of respondents who have a very high internal locus of control, so it can be interpreted that is what they have done before. However, there are still conditions of locus of control students who are at a moderate level. Achievement at a moderate level indicates that there are still people who are having a daily life are their own business, while others are believed to be students as a result of the conditions outside themselves.

TABLE I

OVERVIEW OF THE LOCUS OF INTERNAL CONTROL

\begin{tabular}{|c|c|c|c|}
\hline $\begin{array}{c}\text { Score } \\
\text { Interval }\end{array}$ & Category & Frequency & \% \\
\hline$\geq 59$ & Very high & 10 & 4.6 \\
\hline $47-58$ & High & 175 & 80.2 \\
\hline $35-46$ & Moderate & 33 & 15.2 \\
\hline $23-34$ & Low & 0 & 0 \\
\hline$\leq 22$ & Very Low & 0 & 0 \\
\hline \multicolumn{2}{|c|}{ Total } & 218 & 100 \\
\hline
\end{tabular}

\section{B. Self-Concept}

The individual concept uses positive level category. The research findings presented in Table 2 shows that $52.7 \%$ of students have confidence and assessment of their condition at a positive level; $35.4 \%$ have positive beliefs and understanding about their condition. Although more than $11 \%$ have enough self-concept and they are not positive. In relation to the maturity of entrepreneurship career, can be interpreted as a student has a good concept of self-ability and can develop them as a manifestation of a condition of the self. In developing the potential of entrepreneurship, the condition of self-concept is an important factor that must be owned by students. The more positive self-concept, the ability to stand the test and develop creative business ideas will be better.

TABLE II

OVERVIEW OF SELF-CONCEPT

\begin{tabular}{|c|c|c|c|}
\hline $\begin{array}{c}\text { Score } \\
\text { Interval }\end{array}$ & Category & Frequency & $\%$ \\
\hline$\geq 71$ & Very Positive & 77 & 35.4 \\
\hline $57-70$ & Positive & 115 & 52.7 \\
\hline $43-56$ & Quite Positive & 24 & 11 \\
\hline $29-42$ & Not Positive & 2 & 0.9 \\
\hline$\leq 28$ & $\begin{array}{l}\text { Very Not } \\
\text { Positive }\end{array}$ & 0 & 0 \\
\hline \multicolumn{2}{|c|}{ Total } & 218 & 100 \\
\hline
\end{tabular}


The conditions of these two variables are also described in Graphs 1 and 2. Comparison between predictors shows that increase in internal learning.

\section{Career Maturity}

Research shows that more than half of the respondents have the condition of career entrepreneurship maturity at a high level $(57.3 \%)$. This achievement indicates that students have sufficient maturity index to perform various explorations and planning according to the stage of career development. Nevertheless, exposure in Table 3 shows that more than $30 \%$ of students need a massive increase in career entrepreneurship maturity.

TABLE III

OVERVIEW OF CAREER MATURITY

\begin{tabular}{|c|c|c|c|}
\hline $\begin{array}{c}\text { Score } \\
\text { Interval }\end{array}$ & Category & Frequency & \% \\
\hline$\geq 67$ & Very high & 26 & 12 \\
\hline $54-66$ & High & 125 & 57.3 \\
\hline $41-53$ & Moderate & 59 & 27 \\
\hline $28-40$ & Low & 8 & 3.7 \\
\hline$\leq 27$ & Very Low & 0 & 0 \\
\hline \multicolumn{2}{|c|}{ Total } & 218 & 100 \\
\hline
\end{tabular}

The achievement of career maturity in entrepreneurship becomes one of the main standards in developing entrepreneurship-based education in higher education programs. Research shows some respondents with low levels of career maturity.

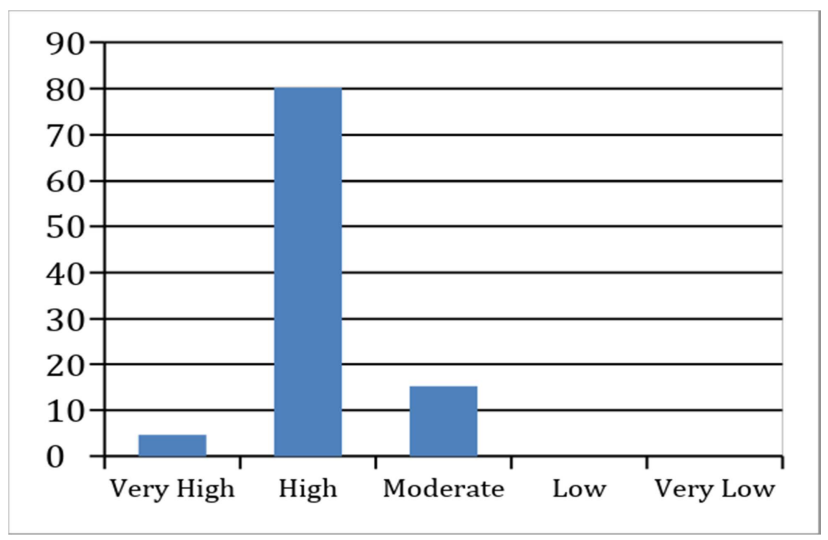

Fig. 1 Student's Internal Locus of Control (in 1-100 scale)

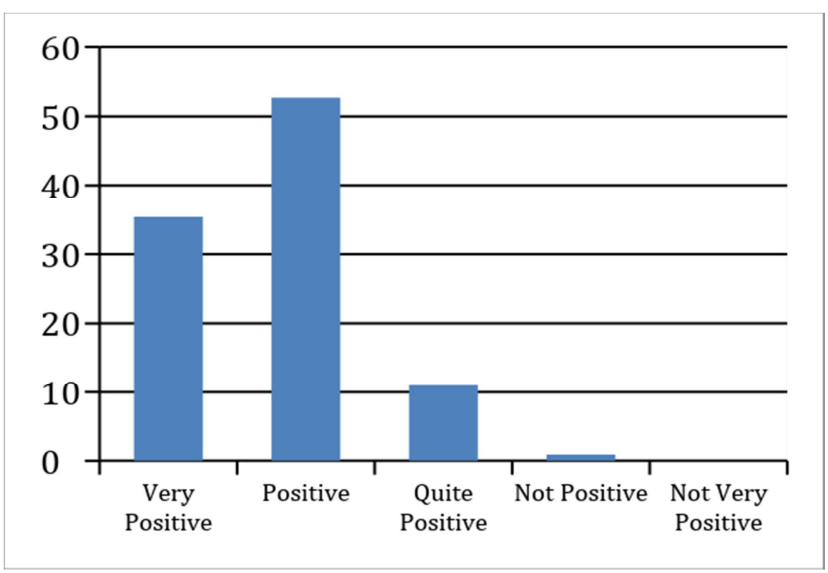

Fig. 2 Personal Self-Concept of Students (in 1-100 scale)

\section{The contribution of Locus of Internal Control and Self Concept to Career Maturity}

The internal contribution of Locus of Control and selfconcept of career maturities were analyzed using multiple regressions and presented in Table 4 . The achievement of Rvalue of 0.275 indicates regression between internal locus of control coefficient $\left(\mathrm{X}_{1}\right)$ on career maturity $(\mathrm{Y})$ on $\mathrm{P}$-value (significance) 0,000 . The value of $R$ Square $\left(R^{2}\right)$ of 0.075 , this means that $7.5 \%$ of the variation in the high-low career maturity can be explained by the internal locus of control, while the remaining $92.5 \%$ is explained by other variables. The achievement of $\mathrm{R}$ values indicates the self-condition that occurs in the individual effects of career maturity in entrepreneurship. This will have an impact on whether the individual is ready or not (in this case, the student who will enter the engineering college) in starting his career as an entrepreneur. The barometer that becomes the starting point of entrepreneurial success is the ability to respond to every opportunity and challenge so that with the internal locus of control is high; it will produce maturity in facing challenges as entrepreneurs. Research findings prove that the more dominant internal locus of control individuals, then contribute to the improvement of career maturity.

The relationship of self-concept with maturity is shown on multiple regression models $\mathrm{X}_{2}-\mathrm{Y}$ in Table 4 . The model test produces the R-value of 0.268 , which shows the regression coefficient between the concepts of career maturity, with a significant level of 0.000 . The value of $\mathrm{R}$ Square $\left(\mathrm{R}^{2}\right)$ of 0.072 ; this means $7.2 \%$ variation in the high level of career maturity can be explained by self-concept. The contribution of self-concept to career maturity is an indicator of the impact of views, perceptions, and beliefs of individuals on improving the maturity of entrepreneurship career [39], [40]. Effectively, self-concept is related to physical dimension, individual character and motivation will give significant manifestation to the ready or not of students for entrepreneurship [41], [42]. Based on these findings, it can be implemented in a higher education context, where it can occur in higher education.

TABLE IV

OVERVIEW OF CAREER MATURITY

\begin{tabular}{|c|c|c|c|}
\hline Model & $\mathrm{R}$ & $\mathrm{R}$ Square & Sig. \\
\hline $\mathrm{X}_{1}-\mathrm{Y}$ & 0.275 & 0.075 & 0,000 \\
\hline $\mathrm{X}_{2}-\mathrm{Y}$ & 0.268 & 0.072 & 0,000 \\
\hline $\mathrm{X}_{1}, \mathrm{X}_{2}-\mathrm{Y}$ & 0.332 & 0.110 & 0,000 \\
\hline
\end{tabular}

Note. $\mathrm{X}_{1}$ : Internal locus of control, $\mathrm{X}_{2}$ : Self-concept, $\mathrm{Y}$ : Maturity career of engineering education students in entrepreneurship

Tests on two variables (X1 and X2) together with the level of entrepreneurship career maturity results is in a value of 0.332 which shows a double regression coefficient between internal locus of control and self-concept of career maturity, with P-value (significance) 0,000. When analyzed from the achievement of $\mathrm{R}$-value, it can be interpreted that the coefficient value is sufficient level, so this indicates that together, internal locus of control and student self-concept has a significant contribution to the condition of career maturity in entrepreneurship. The power of the findings is also evident by the achievement of R Square (R2) of 0.110 ; 
this means that $11 \%$ of the high variation in the low maturity of entrepreneurship can be explained together with by an internal locus of control and self-concept, while the remaining $89 \%$ is explained by other variables.

The acquisition of these values has been strong enough to be the basic reference in mapping the psychological conditions of entrepreneurship. An in-depth study of the internal dimensions of control and students' self-concept in preparation for entrepreneurship is a key indicator in assessing the readiness of students [43], [44]. The individual's self-confidence in self-achievement and its deep understanding of psychological factors determines the maturity of a career in entrepreneurship. The findings of psychological factors determining the maturity of an entrepreneurship career become the basis of entrepreneurship education. The study is in higher education engineering. The diagnosis of internal conditions of locus of control and self-concept in improving student career maturity in entrepreneurship in engineering higher education becomes the focus of study in the preparation of entrepreneurship-based curriculum [45], [46] and creative thinking skills, critical and logical [47].

Entrepreneurship careers in engineering education are also related to the curriculum and how to teach entrepreneurship. The entrepreneurial curriculum challenge, which is the difficulty in teaching students about entrepreneurship, is what educators in engineering education are sure to find because they practice that "theory is boring! College is boring! School is boring!", All theories, lectures, and schools can be relevant to the conditions that occur in the field. We as educators, can also be boring and irrelevant in the eyes of students! Students may not understand that learning theory can be very interesting. Unfortunately, the process that can be used to print entrepreneurship can be boring.

Classes become independent, modeled on learning styles. Classes become irrelevant because it makes us as educators fail to apply theory as a tool to answer student questions. A good theory can pass the test and can be applied in the field. If we fail to teach our students, what is wrong is that we as educators are not theories of discovery. Effective strategies for teaching students must be agreed upon by them and monitored by educators in this way to be more effective. If our goal is to help students become entrepreneurs based on theory, the most effective method is to use a system that allows students to practice the special skills needed. In other words, students can use practice with theory-based activities. The main role of educators is to study the appropriate contracts and identify theories that must be mastered. Questions for educators generally before teaching like this, "What will I teach today?" should "What will my students do today?" The task of educators can make it easier by delegating some of the responsibilities for the second question to students. Activities Delegation of learning to students who are more in-depth, into class, or each can reduce boredom. It also provides an opportunity for educators to work more with other students because they try to understand theories in carrying out their tasks in learning activities.

Entrepreneurship careers in engineering education are also related to the curriculum and how to teach entrepreneurship. If these two important parts are problematic, they will certainly have a negative impact on the Internal Control and Self Concept of engineering students, who have an influence on the maturity career of engineering education students in entrepreneurship.

\section{CONCLUSIONS}

The acquisition of $\mathrm{R}$ Square value of $7.5 \%$, and selfconcept contributed is significant to the entrepreneurial students in engineering higher education. The career maturity is $7.2 \%$. If the contribution of students in entrepreneurship is $11 \%$, it can be interpreted that the two variables are contributing in the direction of improving student career maturity in entrepreneurship in higher engineering education.

These two psychological variables are indications that students are engineering higher education and increasing the maturity of students' career in entrepreneurship needs an analysis of the internal conditions of control and student self-concepts. Procedures for diagnosis are also required, especially in the early years of the lecture process so that entrepreneurship development programs can be prepared and enhanced the competitiveness of students upon completion of the later study.

Development and improvement of internal locus of control is the primary focus of school service providers, in this case, school counsellors. Testing and assessment of real student conditions at the beginning of learning activities is to increase locus of control. The long-term manifestation of this effort is the acquisition of internal locus of control at the end of the learning session, which significantly affects career planning and maturity. This also applies to the student's selfconcept, which at the beginning of the learning session was done assessing the student's condition and knowledge of self-concept.

In order to develop entrepreneurship capability of prospective students, engineering colleges need proper regulation especially related to the condition of student abilities. The optimal development of student ability can be known as the psychological aspects of support, one of the internal locus of control and self-concept.

In addition, engineering colleges require the right curriculum and additional synergies in developing entrepreneurial skills so students produce mature entrepreneurial graduates. Entrepreneurship curriculum is related to how to teach entrepreneurship, namely the skills to teach entrepreneurship based on products. Entrepreneurship education in engineering education is only limited to theoretical and semi-practical conceptual orientation, not yet able to carry out learning innovations based on commercial potential. so that technical education is highly required to carry out entrepreneurial learning based on products that have the selling and needed value in the community.

\section{ACKNOWLEDGMENT}

This work was supported and thanks to Faculty of Education and Training of Universitas Bung Hatta which has facilitated and contributed in conducting the research, lecturers and staff of Faculty of Education and Training and this is part of the research of the ministry of technology 
research and higher education in 2019. The experts which contributed in giving suggestion during the research implementation. Furthermore, thanks to the staff and operators that facilitates the field work.

\section{REFERENCES}

[1] M. Syakir, A. Mahmud, and A. Achmad, "The Model of ICT-Based Career Information Services and Decision-Making Ability of Learners,” Int. J. Environ. Sci. Educ., vol. 11, no. 13, pp. 5969-5979, 2016.

[2] Theresa, L. D, "Factors that Inform Students ' Choice of Study and Career". Journal of Education and Practice, Vol.6. no. 27, pp. 43-50, 2015.

[3] A. Atli, "The Effects of Trait-factor Theory Based Career Counseling Sessions on the Levels of Career Maturity and Indecision of High School Students," Univers. J. Educ. Res., vol. 4, no. 8, pp. 18371847,2016

[4] A. D. Bardick, K. B. Bernes, K. C. Magnusson, and K. D. Witko, “Junior High School Students' Career Plans for the Future," J. Career Dev., vol. 32, no. 3, pp. 250-271, 2015.

[5] S. Coertse and J. M. Schepers, "Some Personality and Cognitive Correlates of Career Maturity," J. Ind. Psychol., vol. 30, no. 2, pp. 56-73, 2004.

[6] A. Novakovic and N. A. Fouad, "Background, Personal, and Environmental Influences on the Career Planning of Adolescent Girls," J. Career Dev., vol. 40, no. 3, pp. 223-244, 2012.

[7] J. Usinger and M. Smith, "Career development in the context of selfconstruction during adolescence," J. Vocat. Behav., vol. 76, no. 3, pp. 580-591, 2010.

[8] S. R. Ting, Y. F. Leung, K. Stewart, A. C. Smith, G. L. Roberts, and S. Dees, "A Preliminary Study of Career Education in Middle School," J. Career Tech. Educ., vol. 27, no. 2, pp. 84-97, 2012.

[9] Central Bureau of Statistics, "Statistics News: Labor Indonesia in August 2016," Status No. 103/11 / Th.XIX, November 7, 2016.

[10] Central Bureau of Statistics, "Statistics News: Labor Indonesia in February 2017," Status No. 47/05 / Th.XX, May 5, 2017.

[11] A. Atli, "Five Factor Personality Traits as Predictor of Career Maturity," Eurasian J. Educ. Res., vol. 68, pp. 151-165, 2017.

[12] N. W. Hidayati, "Pengaruh Layanan Informasi Studi Lanjut terhadap Perencanaan Karir Siswa," Edukasi J. Pendidik., vol. 12, no. 88, pp. 94-101, 2016.

[13] L. Gaylor and J. J. Nicol, "Experiential High School Career Education , Self-Efficacy , and Motivation," Can. J. Educ., vol. 2, no. 2016, 2016

[14] Z. J. Acs, L. Szerb, and A. Lloyd, "The global entrepreneurship and development index," in Global Entrepreneurship and Development Index 2017, Springer, 2017, pp. 29-53.

[15] Y. Liu, K. Z. Peng, Y. Mao, and C.-S. Wong, "Different forms of relationships between engineering interests and career maturity in Chinese context," J. Career Dev., vol. 44, no. 5, pp. 425-439, 2017.

[16] F. Chigunta, "Entrepreneurship as a Possible Solution to Youth Unemployment in Africa," Laboring Learn., pp. 433-451, 2017.

[17] C. Dodd, S. F. Odom, and C. T. Boleman, "The Career Maturity of 4H Healthy Lifestyles Program Participants," J. Youth Dev., vol. 9, no. 3 , pp. 1-13, 2014

[18] W. R. Sterner, "Integrating Existentialism and Super' s Life-Span , Life-Space Approach Existentialism and Career Counseling:," Career Dev. Q., vol. 60, no. June, pp. 152-162, 2012.

[19] Bakri, Norhayati,; Salleh, Tuan Salwani,; \& Zin, Zalhan Mohd, "Designing an Integrated Teaching and Learning of Mathematics and Image Processing in Engineering Technology," International Journal on Advanced Science, Engineering and Information Technology, vol 6, no 4, pp. 548-552, 2016.

[20] Bawamohiddin, A B., \& Razali, R, "Problem-based Learning for Programming Education," International Journal on Advanced Science, Engineering and Information Technology, vol 7, no 6, pp. 2035-2050, 2017

[21] Lee, D H., Cho, S H., Kim, Y, "A Design and Development of the Learning Contents Management based on the Personalized Online Learning," International Journal on Advanced Science, Engineering and Information Technology, vol 8, no 4, pp. 1321-1326, 2018.

[22] I. Sari, Marjohan, and Neviyarni, "Locus of Control dan Perilaku Menyontek serta Implikasinya terhadap Bimbingan dan Konseling (Studi pada Siswa Sekolah Menengah Atas Padang Ganting),' Konselor, vol. 2, no. 1, pp. 267-272, 2013.
[23] S. Arslan and A. Akin, "Metacognition: As a Predictor of One 's Academic Locus of Control," Educ. Sci. Theory Pract., vol. 14, no. 1, pp. 33-39, 2014.

[24] B. D. Pratama and Suharnan, "Hubungan Antara Konsep Diri Dan Internal Locus Of Control Dengan Kematangan Karir Siswa SMA,' Pers. J. Psikol. Indones., vol. 3, no. 03, pp. 213-222, 2014.

[25] M. Çakır, "Investigating Prospective Teachers' Perceived Problemsolving Abilities in Relation to Gender, Major, Place Lived, and Locus of Control," Univers. J. Educ. Res., vol. 5, no. 6, pp. 1030 1038, 2017.

[26] N. Widyastuti and A. Widyowati, "Hubungan Antara Locus of Control Internal dengan Kematangan Karir Pada Siswa SMK N 1 Bantul," Humanitas (Monterey. N. L)., vol. 12, no. 2, pp. 82-89, 2015

[27] N. D. I. Prestiana and T. X. A. Putri, "Internal Locus of Control dan Job Insecurity terhadap Burnout pada Guru Honorer Sekolah Dasar Negeri di Bekasi Selatan," SOUL, vol. 6, no. 1, pp. 57-76, 2013.

[28] Suszek, Hubert., Fronczyk, Krzysztof., Kopera, Maciej., Maliszewski, Norbert, "Implicit and explicit self-concept clarity and psychological adjustment," Personality and Individual Differences, Vol.123, pp. 253-256, 2018.

[29] Prasasti and Laksmiwati, "Perbedaan Kematangan Karir Ditinjau Dari Konsep Diri dan Gender Pada Siswa Kelas X Di SMA PGRI 1 Kota Mojokerto,” J. Psikol. Pendidik., vol. 4, no. 1, pp. 1-7, 2017.

[30] M. Olivera-Aguilar, S. H. Rikoon, O. Gonzalez, Y. Kisbu-Sakarya, and D. P. MacKinnon, "Bias, Type I Error Rates, and Statistical Power of a Latent Mediation Model in the Presence of Violations of Invariance," Educ. Psychol. Meas., vol. 78, no. 3, pp. 460-481, 2018.

[31] R. T. Munoz, S. Brady, and V. Brown, "The psychology of resilience: A model of the relationship of locus of control to hope among survivors of intimate partner violence.," Traumatology (Tallahass. Fla)., vol. 23, no. 1, p. 102, 2017.

[32] P. M. Hash, "Development and Validation of a Music Self-Concept Inventory for College Students," J. Res. Music Educ., vol. 65, no. 2, pp. 203-218, 2017.

[33] Hidayat, H, "How to Implement Technology Science for Entrepreneurship by Using the Product-Based Learning Approach and Participatory Action Learning System in Higher Education?" Advanced Science Letters, 23, pp. 10918-10921. https://doi.org/10.1166/asl.2017.10186

[34] Hidayat, H., \& Yuliana, "The Influence of Entrepreneurship Education and Family Background on Students' Entrepreneurial Interest in Nutritious Traditional Food Start Ups in Indonesia," International Journal of Engineering and Technology(UAE), vol. 7 , no.4, pp. 118-122. 2018. https://doi.org/10.14419/ijet.v7i4.9.20631

[35] Hidayat, H., Herawati, S., Syahmaidi, E., Hidayati, A., \& Ardi, Z. "Designing of technopreneurship scientific learning framework in vocational-based higher education in Indonesia," International Journal of Engineering and Technology(UAE), vol. 7, no. 4, pp. 123127, 2018. https://doi.org/10.14419/ijet.v7i4.9.20632

[36] Ganefri, Hidayat, H., Kusumaningrum, I., \& Mardin, A, "Needs Analysis of Entrepreneurship Pedagogy of Technology and Vocational Education with Production Based Learning Approach in Higher Education," International Journal on Advanced Science, Engineering and Information Technology, vol..7, no.5, pp. 17011707, 2017. http://dx.doi.org/10.18517/ijaseit.7.5.1510

[37] Sharf, Richard S, "Applying career development theory to counseling," Nelson Education, 2016.

[38] Salomone, Paul R, "Tracing Super's theory of vocational development: A 40-year retrospective." Journal of career development, vol. 22, no. 3, pp. 167-184, 1996.

[39] J. Schmutzler, V. Andonova, and L. Diaz-Serrano, "How Context Shapes Entrepreneurial Self-Efficacy as a Driver of Entrepreneurial Intentions: A Multi-level Approach," Entrep. Theory Pract., p. 1042258717753142,2018

[40] R. V Mahto and W. C. McDowell, "Entrepreneurial motivation: a non-entrepreneur's journey to become an entrepreneur," Int. Entrep. Manag. J., pp. 1-14, 2018

[41] F. Liñán, F. Ceresia, and A. Bernal, "Who Intends to Enroll in Entrepreneurship Education? Entrepreneurial Self-Identity as a Precursor," Entrep. Educ. Pedagog., p. 2515127418780491, 2018.

[42] T. Mthanti and K. Ojah, "Entrepreneurial orientation (EO): Measurement and policy implications of entrepreneurship at the macroeconomic level," Res. Policy, vol. 46, no. 4, pp. 724-739, 2017.

[43] K. Ham and H. Lim, "Career Maturity and Quality of Life in Korean Adolescents: A Cross-Lagged Panel Design," Career Dev. Q., vol. 65, no. 3, pp. 250-263, 2017. 
[44] K. A. Atitsogbe, I. A. Moumoula, S. Rochat, J.-P. Antonietti, and J. Rossier, "Engineering interests and career indecision in Switzerland and Burkina Faso: Cross-cultural similarities and differences," J. Vocat. Behav., vol. 107, pp. 126-140, 2018.

[45] A. Yulastri and H. Hidayat, "Developing an Entrepreneurship Module by Using Product-Based Learning Approach in Engineering Education.," Int. J. Environ. Sci. Educ., vol. 12, no. 5, pp. 1097-1109, 2017.

[46] I. Kusumaningrum and H. Hidayat, "Learning Outcomes in Engineering Education: A Business Plan Development by
Production-Based Learning Model Approach.," Int. J. Environ. Sci. Educ., vol. 11, no. 18, pp. 11917-11930, 2016 https://files.eric.ed.gov/fulltext/EJ1122558.pdf

[47] Amrina,Z., Desfitri,R., Zuzano,F., Wahyuni,Y., Hidayat,H., Alfino, J, "Developing Instruments to Measure Students' Logical, Critical, and Creative Thinking Competences for Bung Hatta University Students," International Journal of Engineering and Technology(UAE), vol. 7, no.4, pp. 128-131, 2018 http://dx.doi.org/10.14419/ijet.v7i4.9.20633 